\title{
The Effect Of Product Involvement On Store Preference And Clothing Benefits Sought For African- American Female Students
}

\author{
Courtney Johnson, Southern University and A\&M College, USA \\ Lori Banks, Southern University and A\&M College, USA \\ Devonte' Smith, Southern University and A\&M College, USA \\ Jung-Im Seo, Southern University and A\&M College, USA
}

\begin{abstract}
Clothing is one of the most essential things that human bodies need for the multipurpose reasons. Such clothing has been recognized as the high involvement product for many years, resulting to one of the very interesting subjects in consumer research. The purpose of this study is to investigate the influences of clothing involvement on clothing store preference and clothing benefits sought for African-American female college students. This study demonstrates that African-American female college students are generally satisfied with the current ready-to-wear (RTW) clothing. To purchase such RTW clothing, internet store is revealed as one of very exciting shopping centers. Instead, catalog or mail ordering does not strongly attract to the African-American female college consumers. Compared to other involvement groups, high clothing involvement consumers are actively seeking for the fashion image, one of the factors in clothing benefits sought, as well as actively shopping at department store, specialty stores, outlet stores, and internet in Types of Stores. Interestingly, low involvement consumers are generally less interested in store preference or clothing benefits sought than other involvement groups except for the camouflage benefits.
\end{abstract}

Keywords: Clothing Involvement; Store Preference; Clothing Benefits Sought; African-American Female Students

\section{INTRODUCTION}

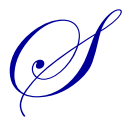

ince humans began to wear clothing about hundred thousand ago, clothing has served many purposes such as protection from the elements or hazardous environments by providing a barrier as a second skin of human body. Such multipurpose clothing is a highly symbolic and visible product as a form of selfexpression and self-image (Kaiser, 1987; Shim and Kotsiopulos, 1991; Oh and Fiorito, 2002; Tortora and Eubank, 2010; Garber, 2013). Many previous researches have generally proved the clothing as the high involvement product in wide variety product categories (Solomon, 1986: Kim, 2005; Zaichkowsky, 1986; Seo 2005; O'Cass, 2004). The concept of clothing involvement is one of the very interesting research themes in consumer research area (Tigert, et al., 1976; Seo et al., 2001; Warrington and Shim, 2000; Seo, 2005; Seo and Namwamba, 2014). As a high involvement fashion-related product, clothing attracts more attention to female consumers rather than male consumers (O'Cass, 2004). However, there is a lack of research on such clothing issue among African-American female consumers even though the purchasing power and the market share of African-American consumers is significantly increased in current markets (Guerra, 2013). In particular, college consumers, especially female students, are considered as one of the most important market segments in the fashion clothing market due to their great spending power (Survey Result, 2014). Understanding the behavior of the cohort of African-American college students is also important for businesses targeting the college segment in the current retail market. Therefore, this study will focus on store preference and clothing benefits sought for African-American female students based on clothing involvement in order to understand their ready-to-wear (RTW) clothing purchasing patterns. Results can be contributed to assist apparel retailers and producers to improve their marketing strategies. Moreover, this research helps to incorporate African-American females into age market segmentation and design of clothing advertisements in current retail area. 


\section{LITERATURE REVIEW}

The concept of product involvement has been recognized as one of the popular research subjects to understand various aspects of consumer behaviors over the last 5 decades (Krugman, 1965, Tigert et al., 1976; Bloch et al., 1986; Rothschild, 1984). One aspect of product involvement is how much individuals care about a particular product (Rothschild, 1986; Zaichkowsky, 1986). The consumers' level of product involvement has a strong influence on the purchasing decision process, product consumption, shopping behaviors and shopping orientation. Product involvement involved various product categories, among which fashion clothing has been considered as the high involvement product (Traylor, 1981; Solomon, 1986; Zaichkowsky, 1986; Warrington an Shim, 2000: O'Cass, 2000; O'Cass, 2004; Seo and Namwamba, 2014; Seo, 2016). Though there are many measurement methods of product involvement, this study used Personal Involvement Inventory (PII) of Zaichkowsky (1986) because PII has been found to be a reliable and valid measure of the clothing and other product involvement construct (Fairhurst et al., 1989).

Depending on the involvement level of clothing, consumers have a different preference for shopping stores/centers. When consumers are highly interested in fashion clothing, they are more likely to shop their clothing at the department or specialty stores. They want to quickly follow the latest trends (Shim and Kotsiopulos, 1992; Seo et al, 2001; Seo and Namwamba, 2014). When consumers are involved with a product, they were expected to reflect its meanings, needs, values, and personality (Shim and Bickle, 1994; Engel et al., 1995; Feinberg et al., 1992). With clothing, consumers want to depict the various benefits such as, social status/prestige, self-improvement, sex appeal, role identification, fashion image, functional/comfort, figure flaws compensation and individuality (Kaiser, 1997; Park and Sullivan, 2009; Shim and Bickle, 1994). As like this, clothing provides many different types of benefits to people. Many researchers have been studied the clothing benefits sought in many years with the majority of Caucasian participants (Aiken, 1963; Park and Sullivan, 2009; Shim and Bickle, 1994; Kinley, 2010).

\section{HYPOTHESES}

This study develops two hypothesis for African-American female consumers. The levels of clothing involvement are significantly correlated with:

Hypothesis 1 (H1): the types of retail stores

Hypothesis 2 (H2): the clothing benefits sought.

\section{MATERIALS AND METHOD}

\subsection{Sampling and Data Collection}

Data were collected from African-American female college students of several universities with various major areas in southeastern United States via questionnaire. This study used a convenience sample method. The authors visited the selected classroom to ask a participation of survey during a regular class session. The questionnaire took 15-20 minutes to complete. Of the 157 questionnaire collected, 135 were completed by females. The majority of respondents were juniors $(n=49,36.3 \%)$, sophomore $(n=38,28.1 \%)$, and seniors $(n=38,28.1 \%)$ with age 19 to $24(n=112,83.0 \%)$. The full time students were $96.3 \%(n=130)$, and $85.2 \%(n=115)$ were single. Almost $70 \%$ of students $(n=94)$ had a full or part time job during their academic year.

\subsection{Questionnaire Design and Measurement}

The questionnaire consists of 4 sections: (1) 8 items for measuring fashion involvement, (2) 7 items of type of stores, (3) 25 items for clothing benefits sought, and (4) 9 items for demographics.

Product Involvement: This study used a short version of Zaichkowsky's Personal Involvement Index (PII) (1986) to measure clothing involvement. The survey participants were asked to complete 8 items on a 7-point semantic differential scale. A factor analysis of Principal-component with varimax rotation extracted only one factor. Cronhach's alpha was $0.92(\mathrm{~F}=6.90, \mathrm{P} \leq .001)$, indicating that 8 items were highly correlated. 
In order to create three levels (low, meddle, and high) of the clothing involvement, this study adopted the method of Warrington and Shim's research (2000), in which respondents were classified into three groups using the formula of a mean score plus or minus half a standard deviation $(M \pm 1 / 2 S D)$. In this work, the mean score $(M)$ of clothing involvement was 5.96 with the standard deviation $(S D)$ of 1.10 , resulting in the classification as follows: the range of low involvement (LI, $n=32,23.7 \%$ ) is from 1 to 5.41 , the range of middle involvement (MI, $n=56,41.5 \%$ ) is from 5.42 to 6.51 , and the range of high involvement (HI, $n=47,34.8 \%$ ) is 6.52 to 7 .

\subsubsection{Types of Retail Stores}

Respondents were asked to indicate how often they generally purchased their clothing at each different type of stores included catalog, discount, department, specialty, off-price, and outlet stores (Shim and Kotsiopulos, 1992). Researchers added internet as type of stores. The 7-point Likert-type scale (i.e. 1=never to 7=Very Often) was used to measure the level of particular store for purchasing clothing.

\subsubsection{Clothing Benefits and Sought}

The scales for clothing benefits sought were adapted from the previous research of Shim and Bickle (1994). Twentyfive Likert-type statements were included to measure clothing benefits sought. Participants indicated the degree of agreement with each statement on a 7-points scale ranging from 1 (strongly disagree) to 7 (strongly agree).

\subsection{Factor Analysis and Reliability Check}

Principal component factor analysis with Varimax rotation was used to perform 25 clothing benefits sought statements (Table 1). The factor loadings less than 0.50 were eliminated, and items with factor loadings greater than 0.50 were retained as a factor. The Eigen-values greater than 1.00 were adopted. Each factor was checked with the Reliability (Cronbach's alpha). This study identified five factors to describe clothing benefits sought: (1) fashion image, (2) satisfaction with RTW clothing, (3) appeal to the opposite sex, and (4) camouflage and (5) emphasize on lower body shape. To test the reliability of the scale, Cronbach's alpha coefficient ranged from 0.416 to 0.746 .

\section{RESULTS}

In order to test hypotheses, multivariate analysis of variance (MANOVA) and univariate analysis of variance (ANOVA) were used. When MANOVA is significant, this study adopts ANOVA to determine how much each level of clothing involvement significantly differs from factors to factors.

Testing Hypothesis 1: Table 2 summarizes the results of MANOVA and ANOVA on the types of stores. MANOVA result indicates that the types of stores significantly differed by three levels of clothing involvement (LI, MI, and HI) $(F=3.21, p \leq .001)$. The individual ANOVA revealed that the three clothing involvement groups (LI, MI, and HI) were significantly different on four types of stores; Department Stores $(F=4.72, p \leq .05)$, Specialty Stores $(F=9.62$, $p \leq .001)$, Outlet Stores $(F=2.49, p \leq .1)$, and Internet $(F=6.88, p \leq .001)$. In other words, the HI group had higher mean scores on Department Store $(M=4.89)$, Specialty Stores $(M=5.79)$, Outlet Stores $(M=4.77)$, and Internet $(M=$ 6.15), whereas the LI group had the lowest mean scores on Department Store $(M=3.81)$, Specialty Stores $(M=4.16)$, Outlet Stores $(M=3.84)$, and Internet $(M=4.72)$. MI group had the lowest mean score on Catalog or Mail Ordering $(M=3.34)$. According to the statistical results, hypothesis 1 was accepted.

Testing Hypothesis 2: Table 3 summarizes the results of MANOVA and ANOVA on clothing benefits sought. The results of MANOVA $(F=2.46, p \leq .05)$ revealed that three involvement groups were significantly different on the overall factors in clothing benefits sought. ANOVA supported that three involvement groups were significantly different on one factor out of five factors: Fashion Image $(F=12.09, p \leq .001)$. Of the three groups, HI group had the highest mean score on Fashion Image $(M=5.29)$, but it had the lowest mean scours on Appeal to Opposite Sex $(M=3.89)$. However, MI group had the highest mean scores on Camouflage $(M=4.30)$ on the factors of clothing benefits sought. LI group had the lowest mean scores on Appeal to Opposite Sex $(M=3.27)$ on the factors of clothing benefits sought. Therefore, the hypothesis 2 was accepted. 


\section{DISCUSSION AND CONCLUSION}

The interesting find in this study is that African-American female college students are more interested in their clothing $(M=5.96$, range 1 7) than Caucasian females $(M=4.98 \sim 5.05$, range 1 7) (Warrington and Shim, 2000; Seo, 2005). This result indicates that African-American female students are strongly attracted to clothing as one of important tools to express their individuality in current fashion trend. To deeply understand this African-American consumers' clothing shopping behaviors, this study investigates preference for types of stores and clothing benefits sought in three levels of individual clothing involvement groups.

Table 1. Principal Component Factor Analysis Results of Clothing Benefits Sought

\begin{tabular}{|c|c|c|c|c|c|}
\hline Factor Name & Items & $\begin{array}{l}\text { Factor } \\
\text { Loading }\end{array}$ & $\begin{array}{l}\text { Eigen- } \\
\text { values }\end{array}$ & $\begin{array}{l}\text { Percentage } \\
\text { of Variance }\end{array}$ & $\begin{array}{c}\text { Alpha } \\
\text { Coefficient }\end{array}$ \\
\hline \multirow{8}{*}{$\begin{array}{l}\text { Factor } 1 \\
\text { Fashion Image }\end{array}$} & I try something new in each season's fashions. & 0.813 & 5.741 & 28.707 & 0.746 \\
\hline & I am willing to try new clothing fashion ideas. & 0.789 & & & \\
\hline & I try to select updated fashions $\&$ accessories. & 0.773 & & & \\
\hline & $\begin{array}{l}\text { I try to select clothes that portray a fashionable } \\
\text { image. }\end{array}$ & 0.754 & & & \\
\hline & I buy clothes that emphasize my femininity. & 0.696 & & & \\
\hline & I like to select clothing that emphasizes my hips. & 0.577 & & & \\
\hline & I am usually the last to try new clothing fashions. & -0.564 & & & \\
\hline & $\begin{array}{l}\text { Wearing the latest styles is important to me in } \\
\text { order to maintain a fashionable image. }\end{array}$ & 0.548 & & & \\
\hline \multirow{4}{*}{$\begin{array}{l}\text { Factor } 2 \\
\text { Satisfaction with } \\
\text { RTW Clothing }\end{array}$} & $\begin{array}{l}\text { I am satisfied with the fit at my waist in ready- } \\
\text { to-wear clothing. }\end{array}$ & 0.786 & 2.097 & 10.486 & 0.734 \\
\hline & $\begin{array}{l}\text { I am satisfied with the fit at my hips in ready-to- } \\
\text { wear clothing. }\end{array}$ & 0.774 & & & \\
\hline & I like to select clothing that emphasizes my legs. & 0.618 & & & \\
\hline & $\begin{array}{l}\text { I like to select clothing which emphasizes my } \\
\text { neck. }\end{array}$ & 0.607 & & & \\
\hline \multirow{2}{*}{$\begin{array}{l}\text { Factor } 3 \\
\text { Appeal to } \\
\text { Opposite Sex }\end{array}$} & I dress to impress the opposite sex. & 0.871 & 1.884 & 9.420 & 0.753 \\
\hline & $\begin{array}{l}\text { Dressing to appeal to the opposite sex is } \\
\text { important to me. }\end{array}$ & 0.831 & & & \\
\hline \multirow{2}{*}{$\begin{array}{l}\text { Factor } 4 \\
\text { Camouflage }\end{array}$} & $\begin{array}{l}\text { I select clothes that will camouflage my figure } \\
\text { problem. }\end{array}$ & 0.855 & 1.778 & 8.889 & 0.755 \\
\hline & I try to cover my figure flaws with clothing. & 0.849 & & & \\
\hline \multirow{4}{*}{$\begin{array}{l}\text { Factor } 5 \\
\text { Emphasis on } \\
\text { Lower Body } \\
\text { Shape }\end{array}$} & $\begin{array}{l}\text { I tend to select clothes that fit tightly to my } \\
\text { figure. }\end{array}$ & 0.634 & 1.445 & 7.227 & 0.416 \\
\hline & $\begin{array}{l}\text { I am satisfied with the fit at my thigh in ready-to- } \\
\text { wear clothing. }\end{array}$ & -0.597 & & & \\
\hline & $\begin{array}{l}\text { I am generally satisfied with the pant lengths in } \\
\text { ready- to wear clothing }\end{array}$ & -0.578 & & & \\
\hline & $\begin{array}{l}\text { I like to select clothing which emphasizes my } \\
\text { waist }\end{array}$ & 0.547 & & & \\
\hline
\end{tabular}


Table 2. Results of MANOVA and ANOVA for Hypothesis 1

\begin{tabular}{|c|c|c|c|c|c|}
\hline & \multicolumn{3}{|c|}{ Group Means } & \multirow[b]{2}{*}{$\begin{array}{c}\text { Univariate } \\
F\end{array}$} & \multirow[b]{2}{*}{$\begin{array}{c}\text { Multivariate } \\
\qquad F\end{array}$} \\
\hline & $\begin{array}{c}\mathrm{LI} \\
n=32\end{array}$ & $\begin{array}{c}\text { MI } \\
n=56\end{array}$ & $\begin{array}{c}\text { HI } \\
n=47\end{array}$ & & \\
\hline Types of Stores & & & & & $3.21 * * *$ \\
\hline Department Stores & 3.81 & 4.84 & 4.89 & $4.72 * *$ & \\
\hline Specialty Stores & 4.16 & 5.42 & 5.79 & $9.62 * * *$ & \\
\hline Discount Stores & 4.34 & 4.70 & 5.06 & 1.15 & \\
\hline Off-Price Stores & 3.88 & 4.20 & 4.66 & 1.85 & \\
\hline Outlet Stores & 3.84 & 4.64 & 4.77 & $2.49 *$ & \\
\hline Catalog or Mail Ordering & 3.81 & 3.34 & 3.94 & 0.91 & \\
\hline Internet & 4.72 & 5.64 & 6.15 & $6.88 * * *$ & \\
\hline
\end{tabular}

Scores ranged from 1 (Never) to 7 (Very Often).

$* * *$. Correlation is significant at the 0.001 level (2-tailed).

**. Correlation is significant at the 0.05 level (2-tailed).

*. Correlation is significant at the 0.1 level (2-tailed).

Table 3. Results of MANOVA and ANOVA for Hypothesis 2

\begin{tabular}{|c|c|c|c|c|c|}
\hline & \multicolumn{3}{|c|}{ Group Means } & \multirow[b]{2}{*}{$\begin{array}{c}\text { Univariate } \\
F\end{array}$} & \multirow[b]{2}{*}{$\begin{array}{c}\text { Multivariate } \\
F\end{array}$} \\
\hline & $\underset{n=32}{\mathbf{L I}}$ & $\underset{n=56}{M I}$ & $\begin{array}{c}\text { HI } \\
n=47\end{array}$ & & \\
\hline Clothing Benefits Sought & & & & & $2.46 * *$ \\
\hline Fashion Image & 4.26 & 4.68 & 5.29 & $12.09 * * *$ & \\
\hline Satisfaction with RTW Clothing & 4.06 & 4.09 & 4.38 & 0.93 & \\
\hline Appeal to Opposite Sex & 3.27 & 3.64 & 3.89 & 1.44 & \\
\hline Camouflage & 4.20 & 4.30 & 4.16 & 0.84 & \\
\hline Emphasize on Lower Body Shap & 3.99 & 4.24 & 4.50 & 2.33 & \\
\hline
\end{tabular}

Scores ranged from 1 (Strongly Disagree) to 7 (Strongly Agree).

***. Correlation is significant at the 0.001 level (2-tailed).

**. Correlation is significant at the 0.05 level (2-tailed).

*. Correlation is significant at the 0.1 level (2-tailed).

The high clothing involvement group comprises $34.8 \%$ of subjects $(n=47)$. This group is significantly different from the other two groups on the types of stores. That is, African-American female students with high clothing involvement are more likely to shop their clothing at the department stores, specialty stores, outlet, and internet (Table 2), which is consistent with the previous researches with the majority of Caucasian (Shim and Kotsiopulos, 1992; Seo et al., 2001; Seo and Namwamba, 2014). However, shopping for clothing through catalog or mail ordering does not strongly attract high involvement African-American female group, which is similar to the results of Shim and Kotsiopulos (1992). Another interesting result is that African-American female students-like to purchase their clothing through internet even though they cannot touch, feel, or try on the clothing, resulting from their heavy academic schedule and hardworking load as well as easy access to new technology such as smartphone. Actually, most college students heavily and easily use the internet as new shopping tool. According to Table 3, the high clothing involvement students are very likely to wear the trendy clothing and express their self-perception throughout the clothing with 5.29 high mean score at Fashion Image $(4=$ neutral score). Therefore, high involvement college students usually tend to check what the hottest fashion clothing is by collecting the fashion information through the internet, resulting to on-line purchase for the newest style clothes to express their personality in creative way. Specialty stores are the second preferred place for them to purchase the clothing. They are generally satisfied with the current RTW clothing. Through the current fashion trends, such as skinny jeans and leggings, African-American college female consumers attempt to emphasize their lower body shape for making an hourglass shape. However, the high involvement group does not wear clothing for an appeal to opposite sex or camouflage reason.

The middle clothing involvement students $(n=56,41.5 \%)$ form the largest involvement group in this study. Their clothing shopping style and clothing benefits sought are very similar to the high clothing involvement group. Catalog or mail ordering is the least interesting type of clothing store to the middle involvement consumers. According to the Table 3, the big difference between high and middle involvement groups is that the middle clothing involvement 
students are more seeking the camouflage benefits through current RTW clothing. They try to emphasize on lower body part in order to form a desirable body shape such as an hourglass shape, with their clothing. They also look for the newest fashion image benefits in their RTW clothing.

The low clothing involvement students $(n=32,23.7 \%)$ are the smallest portion in this study. They are significantly different from two other groups (Table 2 and 3). Department stores and catalog or mail ordering are not attractive places for the low involvement consumers to purchase their clothing. Even though the low involvement consumers are significantly different from the other involvement groups on fashion image, they still have high group mean $(M=4.26)$ on it, meaning that they use the clothing as a tool for expressing their personality. Usually, low involvement consumers are less interested in store preference or clothing benefits sought than other involvement groups. However, they are interested in the camouflage benefits similar to other groups, suggesting that they are looking for the camouflage benefit to hide their actual body shapes through their RTW clothing such as less emphasis on their lower body shape. The interesting result is that RTW clothing is not a tool for the sex appeal benefits in the low clothing involvement consumers $(M=3.27)$.

This study demonstrates that most young college consumers prefer to shop online. College consumers commonly satisfy their current RTW clothing. They use clothing as a tool to express their individuality and to camouflage person's body shape. Clothing is not a tool for appeal to opposite sex in young African-American female college consumers.

\section{LIMITATION, IMPLICATION, AND FUTURE RESEARCH}

There are several limitations in this study such as small sample size $(n=135)$ and localized sampling area (southeastern US), resulting not to reflect broad geographical differences among female college student. This study only focuses on clothing as a main product purchased by female college students. The results in this study are useful for marketing strategies to targeted young African-American consumers. The results improve the understanding of clothing benefit sought and store preference for African-American consumers. To capture the young African-American consumers, the internet stores promptly update their newest fashion style and information on the website. In the future, this study can be extended to other crucial products with broad target participants for African-American's shopping behaviors.

\section{ACKNOWLEDGEMENT}

This research was supported by the Southern University System Foundation 1880 Society (Grant FY 2014-19) and Southern University Agricultural Research \& Extension Center.

\section{AUTHOR BIOGRAPHIES}

Courtney Johnson is currently pursuing a master degree in Apparel, Merchandising and Design at the Iowa State University, Ames, Iowa.

Lori Banks is pursuing a Master of Business Administration (MBA) student at Southern University and A \& M Collage.

Devonte' Smith is a B.S. student in the Apparel Merchandising and Textiles at the Southern University and A \& M College.

Jung-Im Seo is an Assistant Professor of the Department of Family and Consumer Science at Southern University and A\&M College, Baton Rouge, Louisiana, USA. She received her Ph.D. from University of Tennessee, Knoxville. E-mail: jungim_seo@subr.edu (Corresponding author). 


\section{REFERENCES}

Aiken Jr, L. R. (1963). The relationships of dress to selected measures of personality in undergraduate women. The Journal of Social Psychology, 59(1), pp. 119-128.

Bloch, P. H., Sherrell, D. L., and Ridgway, N. M. (1986). Consumer search: An extended framework. Journal of consumer research, 13(1), 119-126.

Engel, J. F., Blackwell, R. D., and Miniard, P. W. (1995). Consumer behavior, $8^{\text {th }}$ ed., Dryden Press Fort Worth, TX

Fairhurst, A. E., Good, L. K., and Gentry, J. W. (1989). Fashion Involvement: An instrument validation procedure. Clothing and Textiles Research Journal, 7 (3), 10-14.

Feinberg, R.A., Mataro, L. and Burroughs, W.J. (1992). Clothing and social identity. Clothing and Textiles Research Journal, 11(1), 18-23.

Garber, M. (November 5, 2013). 'What are clothes?' Askes most delightful Supreme Court argument in history. The Atlantic. . Retrieved from http://www.theatlantic.com/technology/archive/2013/11/what-are-clothes-asks-most-delightfulsupreme-court-argument-in-history/281155/

Guerra, M. (November 7, 2013). Fact Sheet: The state of African American women in the United States. Center for American Progress. Retrieved from http://www.americanprogress.org/wp-content/uploads/2013/11/SOW-factsheet-AA.pdf

Kaiser, S. B. (1997). The social psychology of clothing: Symbolic appearances in context. Fairchild Books.

Kinley, T. R. (2010). Fit and shopping preferences by clothing benefits sought. Journal of Fashion Marketing and Management: An International Journal 14(3), 397-411.

Kim, H. S. (2005). Consumer profiles of apparel product involvement and values. Journal of Fashion Marketing and Management, 9(2), 207-220.

Krugman, H. E. (1965). The impact of television advertising: Learning without Involvement. Public Opinion Quarterly, 29(3), 349-356.

O'Cass, A. (2000). An assessment of consumers product, purchase decision, advertising and consumption involvement in fashion clothing. Journal of Economic Psychology, 21(5), 545-576.

O'Cass, A. (2004). Fashion clothing consumption: antecedents and consequences of fashion clothing involvement. European Journal of Marketing, 38(7), 869-882.

Oh, J., \& Fiorito, S. S. (2002). Korean women's clothing brand loyalty. Journal of Fashion Marketing and Management: An International Journal, 6(3), 206-222.

Park, H. H., and Sullivan, P. (2009). Market segmentation with respect to university students' clothing benefits sought: Shopping orientation, clothing attribute evaluation, and brand repatronage. International Journal of Retail \& Distribution Management, 37(2), 182-201.

Pisut, G., and Connell, L. J. (2007). Fit preferences of female consumers in the USA. Journal of Fashion Marketing and Management: An International Journal, 11(3), 366-379.

Rothschild, M. L. (1984). Perspectives on involvement: current problems and future directions. Advances in consumer research, 11(1), 216-217.

Seo, J.I. (2005). Internet purchasing decision behavior and product involvement. Doctoral dissertation, University of Tennessee, Knoxville, Tennessee.

Seo, J.I. (2016). Internet shopping behaviors of generation Y African-American based on apparel product involvement. International Business Research, 9(9), 64-77.

Seo, J. I., Hathcote, J. M., and Sweaney, A. L. (2001). Casualwear shopping behavior of college men in Georgia, USA. Journal of Fashion Marketing and Management, 5(3), 208-220.

Seo, J.I. and Namwamba, G.W. (2014). The Investigation of Product Involvement in Shopping Behaviors among Male College Students. Atlantic Marketing Journal, 3(3), 81-101.

Shim, S., and Bickle, M. C. (1994). Benefit segments of the female apparel market: Psychographics, shopping orientations, and demographics. Clothing and Textiles Research Journal, 12(2), 1-12.

Shim S., and Kotsiopulos, A. (1992). Patronage behavior of apparel shopping: part I. Shopping orientations, store attributes, information sources, and personal characteristics. Clothing and Textiles Research Journal, 10(2), 48-57.

Solomon, M. R. (1986). Deep-Seated materialism: the case of Live's 501 jeans. In Lutz, R. (Ed). Advances in Consumer Research, 13, Association for Consumer Research, Las Vegas, NV, 619-622.

Survey Results: College Student Buying Behavior (May 2014). http://www.sheerid.com/wp-content/uploads/2014/11/StudentSurvey-Results-Spring-2014.pdf

Tigert, D. J., Ring, L. J., \& King, C. W. (1976). Fashion involvement and buying behavior: A methodological study. NAAdvances in Consumer Research. 3, 46-52.

Tortora, P. G., and Eubank, K. (2010). Survey of historic costume. A\&C Black

Warrington, P., and Shim, S. (2000). An empirical investigation of the relationship between product involvement and brand commitment. Psychology \& Marketing. 17(9), 761-782.

Zaichkowsky, J. L. (1986) Conceptualizing involvement. Journal of Advertising. 15(2), 4-34. 


\section{NOTES}

